\title{
The Influence of Technology Strategies and their Link to Company Performance
}

\author{
Prof Theuns Pelser \\ North-West University \\ E-mail: theuns.pelser@nwu.ac.za
}

\section{Doi:10.5901/mjss.2014.v5n9p238}

\section{Abstract}

The cutting edge of technology management goes beyond basic research and development (R\&D) expenditures. Increasingly, corporate strategists are making a more precise distinction between technology and technology management. The main purpose of this study was to investigate technology strategies in widespread use in technology intensive industries and to explore their relationship to company performance. A non-probability, judgment sample of companies listed on the Johannesburg Stock Exchange (JSE) were taken. The study makes a contribution to the field of strategic management research by integrating the dimensions of several previous studies, to derive a more comprehensive taxonomy of technology strategy archetypes. Two distinct technology factors obtained with the analysis were proved to positively influence the company performance dimensions and were classified as Product Development Intensity and Technology Focus factors. The results show that strategy choices can significantly affect company performance. It thereby indicates which of the underlying dimensions have the strongest relationship with company performance. From an industry perspective, the greatest significance of these findings may be that they accentuate the importance of technology policy in strategic management. The substantial differences in performance associated with the dimensions do not necessarily indicate that a given company should choose a particular technology strategy, but rather indicates that technology policy decisions may have a substantial leverage on a company's performance and should be analysed and exercised with care and deliberation.

Keywords: company performance; product development intensity; strategy dimensions; technology focus; technology strategy

\section{Introduction}

All attempts to understand the effects of technological progress on economic growth, pay homage to Joseph Schumpeter (1961), an Austrian economist remembered for his views on the "creative destruction" associated with industrial cycles. Arguably, the most radical economist of the 20th century, Schumpeter was the first to challenge classical economics as it sought to optimise existing resources within a stable environment-treating any disruption as an external force on par with plagues, politics and the weather. As Schumpeter saw it, a normal, healthy economy was not one in equilibrium but one that was constantly being "disrupted" by technological innovation (Reisman, 2008; Schumpeter, 1961).

International business literature suggests that companies develop competitive advantages in order to ensure success in current markets (Hamel \& Prahalad, 2006; Levitt, 1983; Ohmae, 1989; Panagiotou, 2007). Such advantages tend to be monopolistic assets, either tangible or intangible (Clemens, 2006), such as new technology, patented products, product development capability and marketing skills. In a dynamic global market, companies that generate competitive advantages by effectively integrating research and development, production and marketing activities, tend to ultimately succeed (Pérez-Luñoa et al., 2011).

In coming years, the widely acknowledged importance of technology will grow, increasing the wager executives must place on their companies' ability to compete through technology (Shoham \& Fiegenbaum, 2002). The cutting edge of technology management, however, goes beyond basic research and development (R\&D) expenditures. Increasingly, corporate strategists are making a more precise distinction between "technology" and "technology management." Technology addresses the application of scientific and engineering knowledge to the solution of problems. Technology management, however, has a broader charter as it is the integration of technology throughout the organisation as a source of sustainable competitive advantage (Harmon \& Davenport, 2007).

\section{Background}

A study that addresses company performance with the content dimensions of strategic management requires reviewing and analysing a large and diverse body of literature. It is impractical to attempt to discuss all of the research applicable to 
this topic. This section therefore, only reviews the pioneering research deemed most relevant to the present study. The number of dimensions used to develop strategy taxonomies and the variables required to describe them, have varied by researcher. However, the main thrust of these strategic dimensions is that companies often have a set of strategic goals for improved competitiveness, increased market share and to strengthened their strategic position (Dahan \& Shoham, 2014).

When Miller \& Friesen (1977) derived their strategy archetypes in the late 1970s, they gathered data on 31 variables representing four categories of adaptive behaviour (strategy dimensions). Galbraith \& Schendel (1983) gathered data on 26 variables using the PIMS (Profit Impact of Market Strategy) database. Snow \& Hrebiniak (1980) used a 145 item questionnaire to gather data that were subsequently reduced to ten distinctive competence variables and one performance ratio prior to analysis. Cool \& Schendel (1987) developed fifteen scope and resource commitment dimension variables, based on data drawn from a large variety of databases. Fiegenbaum \& Thomas (1990) used seven scope and resource deployment, and six performance variables. Zahra \& Covin (1993) used four dimensions to develop five business strategy taxonomies and three dimensions for technology strategy. Dvir et al. (1993) used Miles \& Snows' four strategy archetypes and two strategy variables.

\subsection{Technology strategy dimensions}

Technology policies encompass both the contents of technology strategies and the processes of technology management. For this reason, technology strategy is operationalised in this study through the use of six content dimensions, which were derived from prior pioneer studies mentioned and used to guide the selection of the following twelve strategy variables to measure each dimension.

Technology posture refers to a company's propensity to proactively use technology as a competitive weapon and a key-positioning factor (Zahra \& Covin, 1993). Therefore, the variables used to measure this dimension, relate to a company's propensity to accept technical risk (Rauch et al. 2009) and the extent to which reputation building is a conscious goal. Burgelman et al. (1996) and Song et al. (2013), view technological leadership in terms of the relative advantage in the command of technological competencies and capabilities, resulting from a commitment to a pioneering role in the development of a technology, as opposed to a more passive monitoring role.

Technology level refers to the sophistication of the technology employed by the company relative to current advancements of the particular technology (Maidique \& Patch, 1988; Miller, 1988; Clark et al., 1989). It is measured in the study in terms of the number of personnel with post-graduate degrees and the sophistication of the company's research tools and facilities. Technology is a human-created resource comprising various components, which enables a company to perform its productive activities. The enhancement of a company's competitive edge in the marketplace can be accomplished by increasing the advancement of the technology level added by the company's operations. This is achieved through the enhancement of the degree of sophistication of technology components utilised and the level of accumulation of technology capabilities (Sharif, 1997; Shoham \& Fiegenbaum, 2002).

Technology breadth refers to the number of technologies in which the company maintains competence (Dvir et al., 1993). It is measured in the study in terms of the extent of a company's in-house technology base and the diversity of their research references, i.e. intellectual property position. According to Zahra \& Hayton (2008) and (Rauch et al., 2009), the breadth of a company's technology portfolio depends on the company's technology posture, risk orientation , environmental factors, financial resources and the capacity to manage the technology portfolio's complexity.

Product development intensity refers to the number and rate of new product introductions (Miller, 1988; Clark et al., 1989; Dvir et al., 1993; Zahra \& Covin, 1993). It is measured in the study in terms of the emphasis on expanding the product line and the emphasis on introducing improved versions of existing products. According to Kleinschmidt (1994) and Ngamkroeckjoti et al. (2005) new product development (NPD) is critical to the growth and survival of modern companies.

Technology timing refers to a company's propensity to lead or follow competitors in introducing new products (Hung-Chia, 2013; Maidique \& Patch, 1988; Miller, 1988). It is measured in terms of the emphasis a company places on leading the competition in discovering new technologies, introducing products, employing new technologies, or introducing low cost products. A company may pioneer technological change in its industry or follow its competitors' lead (Song et al., 2013). Pioneering and followership represent the two endpoints of a continuum of technological postures, with points between these extremes reflecting different follower positions (Kerin et al., 1992).

Manufacturing and process technology refer to the degree to which new technology is incorporated into the company's manufacturing plants and processes (Zahra \& Covin, 1993). It is measured in terms of the emphasis a company places on the use of technology to achieve low manufacturing costs or to manufacture unique products and to 
improve production flexibility or reduce lead-times. Ensminger et al. (2004) points out, that technical success is often widely accepted as successful implementation.

\subsection{Company performance}

Zahra \& Hayton (2008) established that the literature on performance is very extensive, but that it shows a lack of consensus as to the meaning of the term. Brush \& Vanderwerf (1992) point out, that the use of the term "performance" by researchers includes many constructs measuring alternative aspects of performance. This is consistent with the finding of Murphy et al. (1996) who, after a comprehensive literature review, were able to isolate a total of 71 different measures of performance. In spite of this apparent abundance, the vast majority of studies have used financial measures of performance (Hansen, 2010).

The raison d'être for this fixation with financial performance measures, is found partly in the fact that financial performance is at the core of the organisational control systems and partly in that it is one of the most easily quantifiable measuring instruments. However, this has caused empirical research to rely on a narrow set of accounting measures of financial performance, such as return on investment (ROI), return on assets (ROA), or earnings per share (Pandian, et al., 2006; Sapienca et al., 1988).

The innovation management organisation (IMO) is responsible for developing new products and technologies (Pérez-Luñoa et al., 2011). Science and technology from the external environment are combined with the company's inhouse skills, knowledge and competencies to develop new products and technologies. The responsibilities that fall within the domain of innovation management encompass research and development (R\&D). For this reason, R\&D consists of those activities and responsibilities ranging from understanding progressive technology to generating ideas to developing new products and technologies.

Understanding the dynamics of the innovation management organisation (IMO) is important to understanding the role and impact of strategic leadership of innovation in technology intensive companies. The conceptual definition is, therefore, the extent to which the R\&D manager or other top manager perceives that the IMO has achieved its desired objectives over the last three years.

\section{Problem Statement and Research Hypotheses}

The main purpose of this study was to investigate technology strategies in widespread use in technology intensive industries and to explore their relationship to company performance. Based on the literature review and arguments made, this study proposed the following hypotheses:

H1. Technology Focus has a positive impact on company performance.

H2. Product Development Intensity has a positive impact on company performance.

H3. Process Management has a positive impact on company performance.

\section{Research Methodology}

\subsection{Data requirements}

Several of the pioneer studies on strategic taxonomies gathered research data in the form of management perceptions of their company's objectives or capabilities relative to some benchmark, e.g. the competition's objectives or capabilities. This is consistent with the method recommended by Galbraith \& Schendel (1983) and Panagiotou (2007), and is the method employed in the present study. This method also lends itself to answers that can be provided on a normalised five point Likert Scale, with "three" valued answers being "neutral" or "at the industry norm". The technology strategy dimensions are the result of a substantial body of prior research and include the key dimensions of technology strategy development.

The dimensions pertaining to this study were derived from those most often cited in the literature and are a consolidation of the following studies: Maidique \& Patch (1988), Miller (1988), Clark et al., (1989), Dvir et al., (1993) and Zahra \& Covin (1993). Each dimension measured through the use of two items in the questionnaire. The questionnaire items were designed to permit answers on a five-point interval or Likert Scale. Thirty variables were used to gather data on fifteen dimensions. A survey questionnaire was developed and tested in a small pilot study in order to assess the clarity of the directions and questionnaire items. It was then revised and submitted to five technology strategists to confirm its intelligibility and cognitively confirm the validity of the study dimensions and variables as relating to important 
factors in strategic management of technology.

- Effectiveness of the IMO - (4 input dependent variables).

- Performance of the company - (2 output dependent variables).

The measures selected for this study, demonstrate strong relationships with company performance and had been reviewed in the literature section:

1. Contribution to sales (i.e. right product at the right time).

2. Efficiency of innovation project management (i.e. project success rate).

3. Impact of the innovations (e.g. degree of novelty or technical impact).

4. R\&D expenditure (i.e. investment in R\&D activities).

5. Patent information (i.e. output of R\&D activities).

6. Return on assets (i.e. company financial performance).

Factor analysis was used to reduce the dimensions into identifiable factors. Pearson r-correlation was then used to find the strength and direction of the relationships between the factors and the performance dimensions. The relationships examined, are those between the independent variables and the effectiveness of the innovation management organisation (IMO) and the performance of the company.

\subsection{Sample selection}

A non-probability, judgment sample of companies listed on the Johannesburg Stock Exchange (JSE) was taken. It was decided to use listed companies on the JSE for two primary reasons: (1) Listed companies display a capacity and capability (capital and human resources) for R\&D activities compared to smaller unlisted companies. (2) Quantifiable data (e.g. annual reports) is more readily available for the external stakeholders of listed companies than it is on unlisted companies. Based on the abovementioned screening criteria, it was decided to use the Industrial Consumer sector.

Two hundred companies or divisions were identified and incorporated in the survey after the screening stage. Feedback was received from 89 R\&D managers of these two hundred companies, stating their willingness to participate in the survey. A total of 84 completed responses were received and captured for the study. This translates to a 42 percent response rate from the base of 200 originally identified companies. However, compared to the feedback received from the 89 respondents, it effectively means, that the filtered response rate equates to 94 percent.

The non-response portion of the original sample of 200 companies is comprised of 64 companies. An additional 24 companies have indicated that they are not involved in any type of R\&D activities, which automatically excluded them from the study. Another 23 companies provided feedback or reasons concerning their non-participation in the survey, which ranges from vacant positions in R\&D key functions to a lack of interest of these type of research efforts.

\section{Analysis of Results}

\subsection{Factor analysis: technology strategy}

An attempt was made to factor analyse the twelve original strategy variables (A1 - A12). However, a negative error variance (Heywood case) was encountered with the initial variable set. Heywood cases are a common type of offending estimate, which occurs when the estimated error term for an indicator becomes negative. According to Hair et al. (2010), the problem is remedied either by deleting the indicator or by constraining the measurement error value to be a small positive value. The first alternative is the preferred action prescribed by the authors. Therefore, variables A11 and A12 were deleted from the current technology strategy factor analysis. These two variables were later re-classified under the technology management dimension. The remaining ten strategy variables (A1 - A10) were factor analysed by using the principal axis factoring method. Then using the latent root criterion, two factors were extracted on the basis of the scree plot. Together they accounted for 70.25 percent of the variation in the data. The factors were rotated by using the Varimax rotation method and then used as inputs for the regression and cluster analysis.

The correlation matrix for the ten strategy variables was reviewed to confirm the existence of a substantial number of correlations, which indicates the existence of common factors. All the variables had correlations greater than .22 and almost 60 percent of the matrix elements were greater than .50. Bartlett's test of sphericity confirmed, that the correlation matrix was not an identity matrix. The Kaiser-Meyer-Olsen (KMO) measure as sampling adequacy was .778, which Hair et al. (2010) characterised as "middling", indicating that the degree of correlation between unique factors was low. The anti-image covariance matrix contained few elements with values greater than 0.9 , again confirming the applicability of factor analysis. 
The rotated strategy factor loadings are contained in Table 1. Each survey respondent was asked to report on the importance of each of the variables to his or her company relative to major competitors. The heaviest factor loading for each variable is formatted in bold font style.

Table 1. Rotated technology strategy factor matrix

\begin{tabular}{|clcc|}
\hline Variable & Variable Description & Factor 1 & Factor 2 \\
\hline A2 & Pursuing high-risk, break-through technologies & .934 & .244 \\
A1 & Striving for dominance in key technologies & .898 & .180 \\
A4 & Utilising state-of-the-art tools and facilities & .807 & .347 \\
A5 & Maintaining a broad in-house technology base & .684 & .288 \\
A3 & Hiring R\&D personnel with advanced degrees & .620 & .457 \\
A9 & Being first to discover new technologies & .586 & .203 \\
A6 & Utilising diverse technical reference resources & .564 & .369 \\
A10 & First to introduce low cost or innovative products & .550 & .153 \\
A7 & Increasing total number of products offered & .168 & .973 \\
A8 & Continuously improving existing products & .361 & .735 \\
\hline
\end{tabular}

All of the primary factor loadings used in the factor interpretation exceeded .50 in value. According to Hair et al. (2010), factor loadings greater than \pm .30 are considered to meet the minimal level; loadings of \pm .40 are considered important; and if the loadings are \pm .50 or greater, they are considered more important.

Considering the factor loadings, the rotated factors are interpreted below and visually displayed in Figure 1.

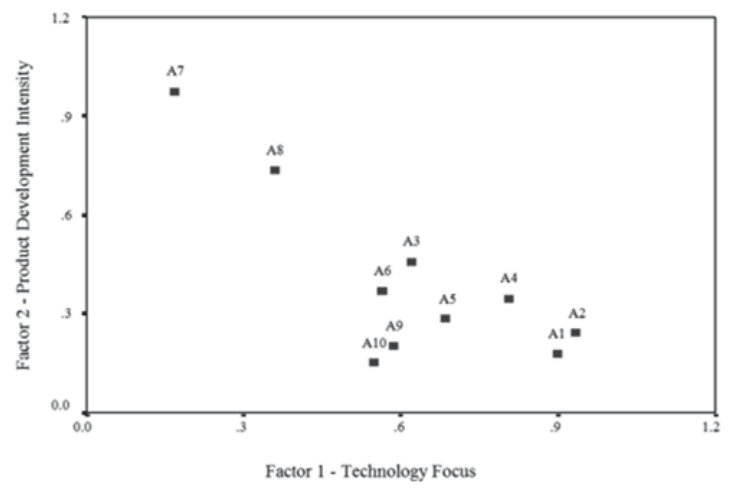

Figure 1: Rotated technology strategy factor plot

1. Technology Focus - The Eigenvalue of the first factor was 5.643. The technology posture variables (A1-A2), technology level variables (A3-A4), technology breadth variables (A5-A6) and the technology timing variables (A9-A8) loaded heavily on this factor. Taken together, this pattern of factor loadings clearly reflects the aggressiveness of a company's technology policy.

2. Product Development Intensity - The Eigenvalue of the second factor was 1.708. The two product development variables (A7-A8) both loaded heavily on this factor. The product development intensity variables were selected to measure the extent to which a company competes on the basis of frequent new product introductions and frequent product upgrades.

\subsection{Factor analysis: company performance}

The methodology for factor analysing the dependent variables, was similar to that used for the previous sections. The six company performance variables (B31 - B36) were factor-analysed by using the principal axis factoring method. Then, using the latent root criterion, two factors were extracted on the basis of their Eigenvalues being greater than 1 . Together they accounted for 75.80 percent of the variation in the data. The factors were rotated by using Varimax rotation method. The same number of methods was used to determine the appropriateness of a factor-analytic model for this analysis.

The correlation matrix for the six company performance variables was reviewed to confirm the existence of a 
substantial number of correlations, which indicates the existence of common factors. All the variables had correlations greater than .16 and more than 40 percent of the matrix elements were greater than .50. Bartlett's test of sphericity confirmed, that the correlation matrix was not an identity matrix. The Kaiser-Meyer-Olsen (KMO) measure as sampling adequacy was .791, which Hair et al. (2010) characterised as "middling". This is also defined as an adequate measure, indicating that the degree of correlation between the unique factors was low. The anti-image covariance matrix contained no elements with values greater than 0.9 , again confirming the applicability of factor analysis.

Based on the Kaiser criterion of selecting factors with Eigenvalues greater than 1, the number of factors to be extracted, were set at two. However, the scree test indicates, that three factors would be retained. In combining these two criteria, two factors were eventually retained for further analysis, because of the very low Eigenvalue (.538) for the third factor. The Chi-square statistic was 235.832 with 15 degrees of freedom, which is significant at the .000 level. The reduced set of variables collectively meets the necessary threshold of sampling adequacy and thus the fundamental requirements for factor analysis.

The final statistics showed, that 75.80 percent of the variance was explained by the two factors. The reproduced correlation matrix contained 3 residual values (20 percent) greater than .05 , indicating that the model fits the data. As a reminder, each respondent was asked to respond to the following questions:

B31. Approximately what percentage of sales over the last three years was due to new products?

B32. Approximately what percentage of innovation projects over the last three years earned a profit?

B33. Approximately what percentage of innovations over the last three years could be considered new-to-the-world breakthroughs?

B34. What is your three-year-average R\&D expenditure as a percentage of sales?

B35. What is your three-year-average number of patents registered per year?

B36. What is your company or division's three-year-average ROA?

The rotated company performance factor loadings are contained in Table 2. The heaviest factor loading for each variable is formatted in bold font style. All of the primary factor loadings used in the factor interpretation, exceeded .50 in value.

Table 2. Rotated company performance factor matrix

\begin{tabular}{|clcc|}
\hline Variable & Variable Description & Factor 1 & Factor 2 \\
\hline B32 & Efficiency of innovation project management & .841 & .308 \\
B33 & Impact of the innovations & .797 & .213 \\
B31 & New product contribution to sales & .773 & .188 \\
B34 & R\&D expenditure & .756 & .123 \\
B35 & Patents registered & .089 & .762 \\
B36 & Return on assets & .308 & .619 \\
\hline
\end{tabular}

1. Input Performance - The conceptual definition for this factor is the extent to which the R\&D manager or other top manager perceives the innovation management organisation has achieved its desired objectives over the last three years. The Eigenvalue of the first factor was 3.167. The four input variables (B31 - B34) loaded heavily on this factor. Taken together, this pattern of factor loadings clearly reflects the effectiveness of the innovation management organisation (IMO).

2. Output Performance - This factor represents the performance of the company where (1) patent information was used to measure R\&D activities and (2) return on assets (ROA) was used to measure company financial performance. The Eigenvalue of the second factor was 1.381. The patent's registered variable (B35) and the return on assets variable (B36) loaded heavily on this factor, indicating the degree of fit for this performance measure.

Considering the factor loadings, the rotated factors are interpreted below and visually displayed in Figure 2. 


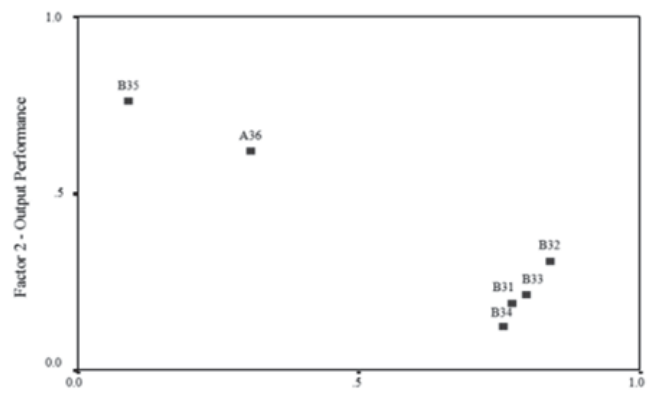

Figure 2: Company performance factor plot

Factor 1 - Input Performance

\subsection{Reliability and validity}

The Cronbach alpha computations for the nine extracted factors are shown in Table 3. For the technology focus coefficient, alpha is .9159; for the product development intensity it is .8685; for the process management it is .8826, and for the input performance it is .8887 . These high values indicate a high degree of data stability.

Table 3. Reliability analysis

\begin{tabular}{|c|c|c|c|c|c|}
\hline Variable & $\begin{array}{l}\text { Scale mean if } \\
\text { item deleted }\end{array}$ & Scale variance if item deleted & $\begin{array}{l}\text { Corrected item } \\
\text { total correlation }\end{array}$ & Alpha if item deleted & Alpha \\
\hline \multicolumn{6}{|c|}{ Technology Focus (TF) } \\
\hline A1 & 24.6190 & 42.6483 & .8570 & .8929 & \multirow{8}{*}{.9159} \\
\hline $\mathrm{A} 2$ & 24.6548 & 41.9637 & .9096 & .8878 & \\
\hline A3 & 24.8333 & 46.6466 & .7085 & .9062 & \\
\hline A4 & 24.6071 & 45.0366 & .8415 & .8955 & \\
\hline A5 & 24.3810 & 46.7929 & .7114 & .9060 & \\
\hline A6 & 24.5476 & 46.9013 & .6231 & .9138 & \\
\hline A9 & 24.9643 & 48.9746 & .5943 & .9149 & \\
\hline A10 & 24.6429 & 50.1360 & .5387 & .9187 & \\
\hline \multicolumn{6}{|c|}{ Product Development Intensity (PDI) } \\
\hline A7 & 3.7976 & 1.0790 & .7785 & - & \multirow{2}{*}{.8685} \\
\hline A8 & 3.7976 & 1.5128 & .7785 & - & \\
\hline \multicolumn{6}{|c|}{ Process Management (PM) } \\
\hline A11 & 3.0476 & 1.2266 & .8108 & - & \multirow{2}{*}{.8826} \\
\hline $\mathrm{A} 12$ & 3.2857 & 1.9415 & .8108 & - & \\
\hline \multicolumn{6}{|c|}{ Input Performance (InP) } \\
\hline B31 & 6.9405 & 13.3820 & .7446 & .8617 & \multirow{4}{*}{.8887} \\
\hline B32 & 7.1429 & 13.0637 & .8234 & .8305 & \\
\hline B33 & 7.6548 & 13.1685 & .7540 & .8584 & \\
\hline B34 & 7.8333 & 15.1044 & .7130 & .8741 & \\
\hline \multicolumn{6}{|c|}{ Output Performance (OutP) } \\
\hline B35 & 21.2381 & 151.9185 & .5015 & - & \multirow{2}{*}{.4104} \\
\hline B36 & 2.4524 & 11.6724 & .5015 & - & \\
\hline
\end{tabular}

Looking at Table 3, it is evident that the output performance factor coefficient alpha is only .4104. However, the data accuracy aspect of reliability can be tested by comparing the test data with external criteria that measure the same variable. In this study the self-reported company return on asset variable (B36) was compared with published financial data from various sources (I-Net Bridge, company reports, etc.). Sixty-seven of 84 respondents correctly reported the return on asset (ROA) category. Fourteen cases exaggerated their ROA by one category and the remaining three cases diminished their ROA by one category. Three Chi-square-based measures of association were calculated, i.e. the phi coefficient, the coefficient of contingency and Cramer's V. Their respective values were 1.26, .63 and .78. All were significant at the .00000 level (rounded to the fifth decimal place), indicating a strong relation between the reported and actual ROA data. These factors point to an acceptably high degree of data reliability. 


\subsection{Multiple regression analysis}

To ascertain the relative importance of the factors in explaining the variation in the dependent variables, multiple regression analysis was used to analyse the relationship between the dependent variables and independent variables. The objective of multiple regression analysis, is to use the independent variables (three factors) whose values are known to predict the single dependent values (two performance factors). The Pearson r-correlations were calculated to find the strength and direction of the relationships between the factors and the performance dimensions. By using $p$-values, it was possible to distinguish between the levels of significance. From Table 4 the null-hypothesis was rejected $(p<0.05$ or $p<$ $0.01)$ for all the factor correlations except for the Process Management factor ( $p>0.05$ or $p>0.01)$.

Table 4. Correlation matrix

\begin{tabular}{|c|c|c|c|c|c|c|}
\hline & & $\begin{array}{l}\text { Technology } \\
\text { Focus }\end{array}$ & $\begin{array}{c}\text { Product Development } \\
\text { Intensity }\end{array}$ & $\begin{array}{c}\text { Process } \\
\text { Management }\end{array}$ & $\begin{array}{c}\text { Input } \\
\text { Performance }\end{array}$ & \begin{tabular}{|c|} 
Output \\
Performance
\end{tabular} \\
\hline $\begin{array}{l}\text { Technology } \\
\text { Focus }\end{array}$ & $\begin{array}{l}\text { Pearson Correlation } \\
\text { Sig. (2-tailed) } \\
\mathrm{N}\end{array}$ & $\begin{array}{c}1.000 \\
84\end{array}$ & $\begin{array}{c}.568^{\star \star} \\
.000 \\
84\end{array}$ & $\begin{array}{l}.039 \\
.727 \\
84\end{array}$ & $\begin{array}{l}.698^{\star \star} \\
.000 \\
84\end{array}$ & $\begin{array}{c}.634^{\star *} \\
.000 \\
84\end{array}$ \\
\hline $\begin{array}{l}\text { Product } \\
\text { Development } \\
\text { Intensity }\end{array}$ & $\begin{array}{l}\text { Pearson Correlation } \\
\text { Sig. (2-tailed) } \\
\mathrm{N}\end{array}$ & $\begin{array}{l}.568^{\star \star} \\
.000 \\
84\end{array}$ & $\begin{array}{c}1.000 \\
84\end{array}$ & $\begin{array}{c}-.020 \\
.853 \\
84\end{array}$ & $\begin{array}{l}.510^{\star \star} \\
.000 \\
84\end{array}$ & $\begin{array}{c}.577^{\star \star} \\
.000 \\
84\end{array}$ \\
\hline \begin{tabular}{|l} 
Process \\
Management
\end{tabular} & $\begin{array}{l}\text { Pearson Correlation } \\
\text { Sig. (2-tailed) } \\
\mathrm{N}\end{array}$ & $\begin{array}{l}.039 \\
.727 \\
84\end{array}$ & $\begin{array}{l}.020 \\
.853 \\
84\end{array}$ & $\begin{array}{c}1.000 \\
84\end{array}$ & $\begin{array}{c}-.195 \\
.075 \\
84\end{array}$ & $\begin{array}{c}-.030 \\
.788 \\
84\end{array}$ \\
\hline $\begin{array}{l}\text { Input } \\
\text { Performance }\end{array}$ & $\begin{array}{l}\text { Pearson Correlation } \\
\text { Sig. (2-tailed) } \\
\text { N }\end{array}$ & $\begin{array}{c}.698^{\star \star} \\
.000 \\
84\end{array}$ & $\begin{array}{c}.510^{\star \star} \\
.000 \\
84\end{array}$ & $\begin{array}{c}.195 \\
.075 \\
84\end{array}$ & $\begin{array}{c}1.000 \\
84\end{array}$ & $\begin{array}{l}.435^{\star *} \\
.000 \\
84\end{array}$ \\
\hline $\begin{array}{l}\text { Output } \\
\text { Performance }\end{array}$ & $\begin{array}{l}\text { Pearson Correlation } \\
\text { Sig. (2-tailed) } \\
\mathrm{N}\end{array}$ & $\begin{array}{c}.634^{\star *} \\
.000 \\
84\end{array}$ & $\begin{array}{c}.577^{\star \star} \\
.000 \\
84\end{array}$ & $\begin{array}{c}-.030 \\
.788 \\
84\end{array}$ & $\begin{array}{l}.435^{\star \star} \\
.000 \\
84\end{array}$ & $\begin{array}{c}1.000 \\
84\end{array}$ \\
\hline
\end{tabular}

**. Correlation is significant at the 0.01 level (2-tailed). *. Correlation is significant at the 0.05 level (2-tailed).

It is apparent from Table 4 that both the Technology Focus and Product Development Intensity factors have a significant positive effect on Input and Output Performance which provide support for the first and second hypothesis. Contrary to the third hypothesis that Process Management positively affects company performance, this factor has negative regression coefficients of -0.195 and -0.030 respectively. The supposition is that companies that make use of technology to achieve low manufacturing costs and to improve production flexibility or reduce lead-times, do little to expand opportunity horizons or renew the organisational competencies. This leads to the reduction in company resources, which creates anxiety that stifles innovation and eliminates R\&D initiatives.

\section{Recommendations}

The Technology Focus factor concerns the role that technology policy plays in the formulation and implementation of business strategies. Technology policies encompass both the contents of technology strategies and the processes of technology management. This factor comprises technology posture, technology level, technology breadth and technology timing. This research indicates that technology policy plays a key role in the formulation and implementation of business strategies. It is recommended that companies use technology proactively as a competitive weapon and a key-positioning factor.

The Product Development Intensity factor indicates the extent to which a company competes on the basis of frequent new product introductions and frequent product upgrades. It is recommended that companies should expand existing product lines and introduce improved versions of existing products to sustain industry leadership.

Finally, the role of the top manager in technology intensive industries has become much more multidimensional. This is recognized by assigning both the Technology Focus (TF) to the top manager and top management team functions. It is recommended that the top manager in technology companies be conscientious with encouraging researcher empowerment, the vast integration of $R \& D$ with the company's business units and a high level of $R \& D$ investment. 


\section{Conclusion}

The present study makes a contribution to the field of strategic management research by integrating the dimensions of several previous studies, to derive a more comprehensive taxonomy of technology strategy archetypes. It also derives a broader set of dimensions for use in strategic management research. The results show that strategy choices can significantly affect company performance. It thereby indicates which of the underlying dimensions have the strongest relationship with company performance.

From an industry perspective, the greatest significance of these findings may be that they accentuate the importance of technology policy in strategic management. The substantial differences in performance associated with the dimensions do not necessarily indicate that a given company should choose a particular technology strategy, but rather indicates that technology policy decisions may have a substantial leverage on a company's performance and should be analysed and exercised with care and deliberation.

\section{References}

Brush, C.G. \& Vanderwerf, P.A. (1992). A comparison of methods and sources for obtaining estimates of new venture performance. Journal of Business Venturing, 7(2), 157-170.

Burgelman, R.A., Maidique, M.A. \& Wheelwright, S.C. (1996). Strategic management of technology and innovation. 2nd ed. New York: McGraw-Hill.

Clemens, C. (2006). Monopolistic competition and entrepreneurial risk-taking. Economics Letters, 93(1), 68-74.

Clark, K., Ford, D. \& Saren, M. (1989). Company technology strategy. R\&D Management, 19(3), 215-229.

Cool, K.O. \& Schendel, D.E. (1987). Strategic group formation and performance: the case of the U.S. pharmaceutical Industry, 19631982. Management Science, 33(9), 1102-1124.

Dahan, G. \& Shoham, A. (2014). Strategic orientations: developing an integrative model of pioneering, entrepreneurial, and stakeholder orientations. Procedia - Social and Behavioral Sciences, 109, 758-762.

Dvir, D., Segev, E. \& Shenhar, A. (1993). Technology's varying impact on the success of strategic business units with the Miles and Snow typology. Strategic Management Journal, 14(2), 155-162.

Ensminger, D.C., Surry, D.W., Porter, B.E., \& Wright, D. (2004). Factors Contributing to the Successful Implementation of Technology Innovations. Educational Technology \& Society, 7(3), 61-72.

Fiegenbaum, A. \& Thomas, H. (1990). Strategic groups and performance: the US insurance industry, 1970-1984. Strategic Management Journal, 11(3), 197-216.

Galbraith, C. \& Schendel, D. (1983). An empirical analysis of strategy types. Strategic Management Journal, 4(2), 153-173.

Hair, J.F. JNR, Black, W.C, Babin, B.J \& Anderson, R.E. (2010). Multivariate data analysis: a global perspective. 7th ed. Upper Saddle River: Pearson Prentice Hall.

Hansen, A. (2010). Nonfinancial performance measures, externalities and target setting: a comparative case study of resolutions through planning. Management Accounting Research, 21(1), 17-39.

Hamel, G. \& Prahalad, C.K. (2006). The core competence of the corporation strategic learning in a knowledge economy. (In Hahn, D. \& Taylor, B., eds. Strategische unternehmungsplanung - strategische unternehmungsführung.) Berlin, Heidelberg: Springer.

Harmon, P. \& Davenport, T. (2007). Business process change. 2nd ed. Burlington, Massachusetts: Morgan Kaufmann.

Hung-Chia, S.H. (2013). Technology timing of IPOs and venture capital incubation. Journal of Corporate Finance, 19(1), 36-55.

Kerin, R.A., Varadarajan, P.R. \& Peterson, R A. (1992). First-mover advantage: a synthesis, conceptual framework and research propositions. Journal of Marketing, 56(4), 33-52.

Kleinschmidt, E.J. (1994). A comparative analysis of new product programmes: European versus North American companies. European Journal of Marketing, 28(7), 5-29.

Levitt, T. (1983). The globalisation of markets. Harvard Business Review, 61(3), 92-102.

Maidique, M.A. \& Patch, P. (1988). Corporate strategy and technological policy. In Tushman, M.L. \& Moore, W.L., eds. Readings in the management of innovation. 2nd ed. Cambridge, MA: Ballinger.

Miles, R.E. \& Snow, C.C. (1978). Organisational strategy, structure and process. New York: McGraw-Hill.

Miller, A. (1988). A taxonomy of technological settings with related strategies and performance levels. Strategic Management Journal, 9(3), 239-254.

Miller, D. \& Friesen, F. (1977). Archetypes of strategy formulation. Management Science, 24(9), 921-933.

Murphy, G.B., Trailer, J.M. \& Hill, R.C. (1996). Measuring performance in entrepreneurship research. Journal of Business Research, $36(1), 15-23$

Ngamkroeckjoti, C., Speece, M. \& Dimmitt, N.J. (2005). Environmental scanning in Thai food SMEs: the impact of technology strategy and technology turbulence. British Food Journal, 107(5), 285-305.

Ohmae, K. (1989). Managing in a borderless world. Harvard Business Review, 67(3), 152-161.

Panagiotou, G. (2007). Reference theory: strategic groups and competitive benchmarking. Management Decision, 45(10), 1595-1621.

Pandian, J.R, Thomas, H. Furrer, O. \& Bogner, W.C. (2006). Performance differences across strategic groups: an examination of financial market-based performance measures. Strategic Change, 15(6), 373-383. 
Parasuraman, A., Grewal, D. \& Krishnan, R. (2007). Marketing research. 2nd ed. Boston, MA: Houghton Mifflin Harcourt.

Pérez-Luñoa, A., Wiklundb, J. \& Cabrera, R.A. (2011). The dual nature of innovative activity: how entrepreneurial orientation influences innovation generation and adoption. Journal of Business Venturing, 26(5), 555-571.

Rauch, A., Wiklund, J., Freese, M. \& Lumpkin, T. (2009). Entrepreneurial orientation and business performance: cumulative empirical evidence. Entrepreneurship Theory and Practice, 33(3), 761-779.

Reisman, D. (2008). Schumpeter on the Economics of Innovation and Heertje's. Research in the History of Economic Thought and Methodology, 26(1), 235-254.

Sapienza, H.J., Smith, K.G. \& Gannon, M.J. (1988). Using subjective evaluations of organizational performance in small business research. American Journal of Small Business, 12(3), 45-53.

Schumpeter, J.A. (1961). The theory of economic development: an inquiry into profits, capital, credit, interest, and the business cycle. New Brunswick: Transaction Publishers.

Sharif, M.N. (1997). Technology strategy in developing countries: evolving from comparative to competitive advantage. International Journal Technology Management, 14(2-4), 309-43.

Shin, J. \& Lee, H. (2013). Low-risk opportunity recognition from mature technologies for SMEs. Journal of Engineering and Technology Management, 30(4), 402-418.

Shoham, A. \& Fiegenbaum, A. (2002), Competitive determinants of organisational risk-taking attitude: the role of strategic reference points. Management Decision, 40(2), 127-141.

Snow, C.C. \& Hrebiniak, L.G. (1980). Strategy, distinctive competence and organisational performance. Administrative Science Quarterly, 25(2), 317-336.

Song, M., Zhao, Y.L. \& Di Benedetto, C.A. (2013). Do perceived pioneering advantages lead to first-mover decisions? Journal of Business Research, 66(8), 1143-1152.

Zahra, S.A. (1996). Technology strategy and financial performance: examining the moderating role of the firm's competitive environment. Journal of Business Venturing, 11(3), 189-219.

Zahra, S.A. \& Covin, J. (1993). Business strategy, technology policy and firm performance. Strategic Management Journal, 14(6), 451478.

Zahra, S.A. \& Hayton, J.C. (2008). The Effect of international venturing on firm performance: the moderating influence of absorptive capacity. Journal of Business Venturing, 23(2), 195-220. 